\title{
State Waiver and Forfeiture of the Exhaustion Requirement in Habeas Corpus Actions
}

Since 1867 federal courts have had the power to issue the writ of habeas corpus to free a person imprisoned by one of the states in violation of the Constitution or laws of the United States. ${ }^{x}$ A prisoner must exhaust all available state remedies, however, before seeking a habeas writ in federal court. ${ }^{2}$ By providing state courts ample opportunity to correct their own errors, the rule reduces friction between federal and state governments due to federal interference in state court judgments. ${ }^{3}$ Originally a judicial doctrine, ${ }^{4}$ this exhaustion requirement was codified in 1948 in 28 U.S.C. § $2254^{\circ}$ ("section 2254").

Although the statute is absolute in its terms and allows for only one carefully defined exception, ${ }^{6}$ federal courts are divided over whether a state's attorney can waive, concede, ${ }^{7}$ or forfeit ${ }^{8}$ the

${ }^{2}$ Act of Feb. 5, 1867, ch. 28, 14 Stat. 385 (current version at 28 U.S.C. $\$ 2241$ (1976)). For a brief history of federal habeas corpus statutes see Longsdorf, The Federal Habeas Corpus Acts Original and Amended, 13 F.R.D. 407 (1953).

28 U.S.C. § 2254(b) (1976).

- See Preiser v. Rodriguez, 411 U.S. 475, 491 (1973) ("rule of exhaustion . . . is rooted in considerations of federal-state comity"). See also infra notes 74-81 and accompanying text.

'See, e.g., Ex parte Hawk, 321 U.S. 114, 116-17 (1944); Ex parte Royall, 117 U.S. 241, 250-53 (1886).

See Judicial Code of 1948, ch. 646, § 2254, 62 Stat. 869, 967 (codified as amended at 28 U.S.C. $\$ 2254$ (b)-(c) (1976)). The statute currently provides:

(b) An application for a writ of habeas corpus in behalf of a person in custody pursuant to the judgment of a State court shall not be granted unless it appears that the applicant has exhausted the remedies available in the courts of the State, or that there is either an absence of available State corrective process or the existence of circumstances rendering such process ineffective to protect the rights of the prisoner.

(c) An applicant shall not be deemed to have exhausted the remedies available in the courts of the State, within the meaning of this section, if he has the right under the law of the State to raise, by any available procedure, the question presented.

28 U.S.C. § 2254 (b)-(c) (1976).

- An application for a writ of habeas corpus based on unexhausted claims may be granted if "it appears . . . that there is either an absence of available state corrective process or the existence of circumstances rendering such process ineffective to protect the rights of the prisoner." 28 U.S.C. \& 2254(b).

"Courts often do not distinguish between waivers and concessions. See, e.g., Collins v. Auger, 577 F.2d 1107, 1109 n.1 (8th Cir. 1978), cert. denied, 439 U.S. 1133 (1979). 
requirement. Some courts have held that states may not waive the requirement. ${ }^{9}$ Others have allowed explicit waivers and concessions, ${ }^{10}$ and one court declared section 2254 inapplicable when the state failed to brief the issue. ${ }^{11}$ Several court of appeals panels have barred states from raising the exhaustion issue when it was not first contested in the district court; ${ }^{12}$ others have overlooked

- Barring a claim for prior failure to raise the issue, commonly called forfeiture, might be considered a waiver by default. This would be inconsistent with the traditional notion that "[a] waiver is ordinarily an intentional relinquishment or abandonment of a known right or privilege," Johnson v. Zerbst, 304 U.S. 458, 464 (1938) (emphasis added). Some scholars would define waiver more broadly. E.g., Rubin, Toward a General Theory of Waiver, 28 U.C.L.A. L. Rev. 478, 514-15 (1981) (waiver includes a subset "governed by the principle of stage preclusion," which "demands that a right be asserted during the stage to which it is most relevant"). But cf. Westen, Away from Waiver: A Rationale for the Forfeiture of Constitutional Rights in Criminal Procedure, 75 Mrch. L. Rev. 1214, 1214 (1977) (calling the same thing forfeiture).

Because waiver has long been used to describe very different phenomena, it has been argued that "[t]echnical use of the word as descriptive of a legal situation is indefensible." J. Ehart, Waiver Distributed 14 (1917). In keeping with the Johnson characterization of waiver as "intentional," 304 U.S. at 464, this comment will follow the Westen terminology and use the term forfeiture for what Rubin calls stage preclusion waivers.

- See, e.g., Sweet v. Cupp, 640 F.2d 233, 237 n.5 (9th Cir. 1981); United States ex rel. Trantino v. Hatrack, 563 F.2d 86, 96 (3d Cir. 1977), cert. denied, 435 U.S. 928 (1978); United States ex rel. Sostre v. Festa, 513 F.2d 1313, 1314 n.1 (2d Cir.), cert. denied, 423 U.S. 841 (1975); Needel v. Scafati, 412 F.2d 761, 766 (1st Cir.), cert. denied, 396 U.S. 861 (1969). Cf. Davis v. Campbell, 608 F.2d 317, 320 (8th Cir. 1979) (per curiam) (erroneous concession of exhaustion does not satisfy $\S 2254$ (b)); Zicarelli v. Gray, 543 F.2d 466, 471 (3d Cir. 1976) (en banc) (state counsel's concession that exhaustion requirement had been satisfied insuffcient to "dispose of the element of exhaustion without an independent judicial inquiry").

${ }^{10}$ See, e.g., Collins v. Auger, 577 F.2d 1107, 1109 n.1 (8th Cir. 1978) (court may accept state waiver), cert. denied, 439 U.S. 1133 (1979); Houston v. Estelle, 569 F.2d 372, 375 (5th Cir. 1978) (state may waive); Jenkins v. Fitzberger, 440 F.2d 1188, 1189 (4th Cir. 1971) (explicit waiver given effect); Tolg v. Grimes, 355 F.2d 92, 97 (5th Cir.) (waiver allowed where state recognizes that "substantial justice will be furthered"), cert. denied, 384 U.S. 988 (1966). Courts will often cite a state's acquiescence to bolster its conclusion that the exhaustion requirement is not a bar to consideration of the petition. See, e.g., Braden v. 30th Judicial Circuit Court, 410 U.S. 484, 492 (1973) (Court notes state's apparent concession of exhaustion requirement); Batten v. Scurr, 649 F.2d 564, 568 (8th Cir. 1981) (defendant not required to exhaust state remedies where state conceded the issue and expended substantial effort litigating federal claim); Bishop v. Wainwright, 511 F.2d 664, $665 \mathrm{n.2}$ (5th Cir. 1975) (court notes state's failure to dispute satisfaction of exhaustion requirement), cert. denied, 425 U.S. 980 (1976).

11 See Lopez v. Smith, 515 F. Supp. 753, 754 (S.D.N.Y. 1981).

12 See, e.g., Hopkins v. Jarvis, 648 F.2d 981, 983 n.2 (5th Cir. 1981) (failure to raise exhaustion in the district court "ordinarily constitutes a waiver"); Messelt v. Alabama, 595 F.2d 247, 250-51 (5th Cir. 1979) (per curiam) (state cannot challenge exhaustion for the first time on appeal); United States ex rel. Graham v. Mancusi, 457 F.2d 463, 467-68 (2d Cir. 1972) ("when the State has sat by for seven years after the filing of this petition without making any suggestion that [exhaustion] is required" court may deal with petition on the merits). Cf. Colon v. Fogg, 603 F.2d 403, 406-07 (2d Cir. 1979) (summary rejection of codefendant's identical claim, state consent to amendment of petition in order to add the claim, and state's failure to raise the exhaustion issue until 14 months later made motion to 
this failure ${ }^{13}$ and some have even raised the issue on their own initiative. ${ }^{14}$ The Supreme Court has not yet considered the issue.

That a statutory requirement, absolute in its terms, can be subject to waiver and forfeiture is established easily enough. Many procedural and substantive requirements, even constitutional barriers, disappear at the request or neglect of the interested party without the aid of any operative language in the requirement itself. ${ }^{15}$ The more difficult question, and the subject of this comment, is whether the exhaustion requirement should be subject to waiver and forfeiture and, if so, under what circumstances. The legislative history of section 2254 gives no indication that Congress considered this question; the articulated legislative objectives only suggest what Congress might have intended had it thought about the issue. Answers consistent with the policies behind the exhaustion requirement can be formulated, but the answers, like the policies, conflict with one another. The treatment of other comparable requirements suggests ways of resolving these ambiguities. After examining the codification of the exhaustion requirement and the policies Congress intended it to serve, this comment compares how waiver and forfeiture problems have been resolved by the courts for requirements serving similar policies. The comment concludes that waiver or concession of the exhaustion requirement should be allowed, that failure to raise the issue in the district court should foreclose consideration of it on appeal, and that an erroneous concession that the requirement has been satisfied should be binding at the appellate level.

\section{Development and Codification of the Exhaustion REQUIREMENT}

When Congress included an exhaustion requirement for habeas corpus petititons in the Judicial Code of $1948^{16}$ (the

dismiss for failure to exhaust " 'close to frivolous' " (quoting district court)). The Supreme Court appeared to sanction a limited form of forfeiture of an exhaustion defense in Smith v. Goguen, 415 U.S. 566, 576-77 (1974) (Court notes that appellant's exhaustion argument "is belatedly raised," not having been presented in the district court, but finds that the requirement had been satisfied) (dictum).

is See United States ex rel. Johnson v. Vincent, 507 F.2d 1309, 1312 (2d Cir. 1974) (failure to raise exhaustion issue in the district court does not bar consideration of it on appeal), cert. denied, 420 U.S. 994 (1975).

14 See United States ex rel. Lockett v. Illinois Parole \& Pardon Bd., 600 F.2d 116, 118 (7th Cir. 1979) ("there is no bar to our raising the issue of exhaustion on our own, although it has not been raised by the State").

${ }^{15}$ See generally infra notes 104-54 and accompanying text.

16 Judicial Code of 1948 , ch. $646, \S 2254,62$ Stat. 869,967 (codified as amended at 28 
"Code") it was merely following established judicial practice. ${ }^{17}$ Questions of waiver and forfeiture arose only after the rule was codified and thus were not addressed in pre-Code case law. Congress left little sign in the statute, its legislative history, or subsequent amendments of having considered these questions.

\section{A. Ex parte Hawk and the Pre-Code Development of the Ex- haustion Requirement}

Pre-Code case law arguably is not relevant to the problem of waiver and forfeiture, because before the Code there was no statutory exhaustion requirement to waive or forfeit.18 Section 2254 was designed, however, to enact pre-Code judicial doctrine. The Reviser's note for the Judicial Code states that section 2254 "is declaratory of existing law as affirmed by the Supreme Court"19 in Ex parte Hawk. ${ }^{20}$ Any rule of waiver and forfeiture should at least be consistent with the doctrine Congress intended to incorporate in the statute.

In a brief per curiam opinion, ${ }^{21}$ the Court did little more in $E x$

U.S.C. § 2254(b)-(c) (1976)).

17 See infra notes 19-32 and accompanying text.

1s The 1867 habeas corpus statute said nothing about exhaustion but simply commanded that writs be granted to those "restrained of [their] liberty in violation of the constitution." Act of Feb. 5, 1867, ch. 28, 14 Stat. 385, 385 (current version at 28 U.S.C. $\$ 2241$ (1976)). It therefore required an exercise of judicial discretion for a federal court to dismiss a habeas corpus petition for failure to exhaust state remedies. The question of whether a state's attorney could block this exercise of discretion by waiving or conceding the exhaustion requirement was never addressed. Now that the requirement has been enacted into law, however, it takes an exercise of judicial discretion not to dismiss a habeas corpus petition if state remedies are not exhausted, unless the specific exceptions of 28 U.S.C. \& 2254(b) (1976) are invoked. See supra note 6 and accompanying text.

1928 U.S.C. \& 2254 note (1976) (Historical and Revision Notes). The Reviser's notes were included in the House Judiciary Committee Report on the Code revision, H.R. REP. No. 308, 80th Cong., 1st Sess. at app. (1947) [hereinafter cited as HousE REPORT], reprinted in 1948 U.S. Code Cong. Serv. (Specinl Supp.) 1692, 1701-1939. See also Galston, An Introduction to the New Federal Judicial Code, 8 F.R.D. 201, 205 (1949) ("[s]ection 2254 . . . conforms to existing decision law"). Cf. Longsdorf, supra note 1, at 416 ("It is well known that the Committee of Judges [see infra note 40 and accompanying text] was set to the task of bettering the Habeas Corpus Act of 1867, rather than to that of essential innovation. Changes were bound to be made, but changes in substantive remedial rights were not contemplated and were not made."). But cf. Wright, Foreword to Legislative History of TrTLE 28, United States Code "Judiciary and Judicial Procedure" at III (R. Mersky \& J. Jacobstein eds. 1971) ("The Reviser's Notes suggest that often the Reviser was wholly unaware of the significance of what he was doing.").

${ }^{20} 321$ U.S. 114 (1944).

21 Hawk was serving a sentence for murder in Nebraska. He had made a number of applications for relief to both federal and state courts. The Supreme Court had twice denied certiorari, 317 U.S. 697 (1943); 311 U.S. 645 (1940), and denied an earlier petition for habeas corpus, 318 U.S. 746 (1943). Hawk's petition was based on an alleged denial of effective 
parte Hawk than recite the basic rule of exhaustion ${ }^{22}$ and list the major cases in its development. ${ }^{23}$ The brevity of the opinion and its reliance on earlier decisions suggest that the Court intended merely to summarize and perpetuate the doctrine of the earlier cases, perhaps with an eye to the codification process then underway. ${ }^{24}$

The Court had frequently noted since its earliest decisions that the judicial exhaustion requirement was discretionary in nature, designed to regulate the federal power to issue the writ of habeas corpus when state courts had not yet completed their proceedings. $^{25}$ In its first exhaustion decision, Ex parte Royall, ${ }^{26}$ the Court stressed the discretionary nature of the requirement. ${ }^{27}$ "That discretion should be exercised in the light of the relations ... between the judicial tribunals of the Union and of the States, and in recognition of the fact that the public good requires that those relations be not disturbed by unnecessary conflict between courts equally bound" to uphold the Constitution. ${ }^{28}$ In Tinsley $v$. Anderson, ${ }^{29}$ the Court drew a clear distinction between a federal court's "power" to grant a writ of habeas corpus and the policy that it "ought not to exercise that jurisdiction" unless state reme-

assistance of counsel and the alleged use of perjured evidence at his trial. See 321 U.S. at 115-16. These claims had been presented as an original matter to the Nebraska Supreme Court in an application for habeas corpus, but the application was denied because that court does not ordinarily hear original petitions for habeas corpus. See id. at 116.

${ }^{22}$ Ordinarily an application for habeas corpus by one detained under a state court judgment of conviction for crime will be entertained by a federal court only after all state remedies available, including all appellate remedies in the state courts and in this Court by appeal or writ of certiorari, have been exhausted.

321 U.S. at 116-17 (citations omitted). Where state remedies have not been exhausted "the federal courts . . . will interfere with the administration of justice in the state courts only 'in rare cases where exceptional circumstances of peculiar urgency are shown to exist.' "Id. at 117 (quoting United States ex rel. Kennedy v. Taylor, 269 U.S. 13, 17 (1925)) (citations omitted).

${ }^{23}$ See id. at 116-18.

24 The Hawk opinion was issued in January of 1944, id. at 114, only a few months after the Judicial Conference approved proposals for habeas corpus legislation, see infra notes 39 . 43 and accompanying text.

${ }^{23}$ See Laubach, Exhaustion of State Remedies as a Prerequisite to Federal Habeas Corpus: A Summary, 1966-1971, 7 Gonz. L. REv. 34, 36 (1971).

${ }^{28} 117$ U.S. 241 (1886). Royall was not cited by the Court in Hawk but is cited in many of the cases cited in Hawk. See, e.g., Tinsley v. Anderson, 171 U.S. 101, 105 (1898), cited in Hawk, 321 U.S. at 117.

${ }^{27}$ See 117 U.S. at 250-54.

${ }^{28}$ Id. at 251 . Cf. Laubach, supra note 25 , at 36 (the exhaustion requirement of Royall "was not a binding rule but merely a procedure which, in the interests of federalism, should normally be followed").

29 171 U.S. 101 (1898). 
dies have been exhausted. ${ }^{30}$ And in United States ex rel. Kennedy v. Tyler, ${ }^{31}$ the Court emphasized that the statutory power to issue the writ on application of a prisoner held by authority of state law "is not unqualified, but is to be exerted in the exercise of a sound discretion." 32

Nothing in Hawk indicates that the court intended to alter the traditionally discretionary nature of the exhaustion rule. Although the pre-Code cases cannot resolve the issue, it would not be fully consistent with the discretionary rule they created and section 2254 adopted to construe the statute so as to foreclose all discretion to allow waiver and forfeiture.

\section{B. Legislative History of Section 2254}

Congress enacted section 2254 as part of its revision of the Judicial Code in $1948 .{ }^{33}$ Considering the sheer volume of law created by the enactment of the Code, ${ }^{34}$ its legislative history is rather meager. ${ }^{35}$ With about one page devoted to it in the Senate Report ${ }^{38}$ and passing mention on the Senate floor, ${ }^{37}$ section 2254 was given, if anything, disproportionate attention for such a small part of this major piece of legislation..$^{38}$

Even before Congress's Code revision began, ${ }^{39}$ the Judicial

so Id. at 104-05.

31269 U.S. 13 (1925).

s2 Id. at 17.

2s See supra note 5 and accompanying text.

24 The scope and nature of the 1948 revision and codification has been described by three principal participants in the process. See Barron, The Judicial Code: 1948 Revision, 8 F.R.D. 439 (1949) (Chief Reviser, Title 28); Galston, supra note 19 (member, Judicial Conference Committee on Revision of the Judicial Code); Holtzoff, The New Federal Judicial Code, 8 F.R.D. 343 (1949) (Special Consultant on the Revision Staff). The 1948 Code has more recently been described in critical terms. See Wright, supra note 19, at III ("The Judicial Code of 1948 is not a distinguished document.").

ss Legislative materials related to the enactment of the Judicial Code of 1948 are collected in 1948 U.S. Code Cong. SeRv. (SPEcial SupP.) 1487-2174, and more recently in LsGislative History of Titze 28, United States Code "Judiciary and Judicial Procedure" (R. Mersky \& J. Jacobstein eds. 1971) [hereinafter cited as LegisLatrve History of TimLs 28].

36 S. RzP. No. 1559, 80th Cong., 2d Sess. 9-10 (1948) [hereinafter cited as SzNATE RiPORT], reprinted in 1948 U.S. Code Cong. SkRv. (Sprcial Supr.) at 1683-84.

${ }^{27}$ See 94 Cong. Rac. 7928 (1948) (statement of Sen. Donnell).

${ }^{28}$ The only genuine controversy evident in the legislative materials was whether to include the Tax Court in the Judicial Code. The bulk of the Senate Report is devoted to excising all references to the Tax Court from the version of the Code passed in the House. See Senate Report, supra note 36, at 2, reprinted in 1948 U.S. Code Cong. Skrv. (Spgcial Supp.) at 1676. The House accepted the Senate amendments after only brief debate. See 94 Cong. REc. 8498-501 (1948). See also Galston, supra note 19, at 206.

s" The process of drafting the 1948 Judicial Code is described in House REPORT, supra 
Conference of Senior Circuit Judges (the "Conference") had initiated action aimed at reforming federal habeas corpus legislation. ${ }^{40}$ The Conference adopted two legislative proposals in 1943, one dealing with habeas corpus procedure, "the other limiting the jurisdiction of federal courts to issue the writ." ${ }^{11}$ The so-called "jurisdictional bill"42 included a section codifying the exhaustion requirement. ${ }^{43}$ In 1947 the House passed a version of the Code that incorporated much of what the Conference desired, though not characterizing the exhaustion requirement as jurisdictional.44 The Conference endorsed the House version and recommended two amendments to the habeas corpus sections in the Code, ${ }^{45}$ both of which Congress adopted. ${ }^{46}$

Had Congress followed the Judicial Conference and used the term "jurisdictional" to characterize the exhaustion requirement, the question of waiver and forfeiture might never have arisen. A requirement that goes to a court's subject matter jurisdiction must

note 19, at 1-8, reprinted in 1948 U.S. Code Cong. Serv. (Special Supp.) at 1692-99. See also Barron, supra note 34, at 439-40; Galston, supra note 19, at 201-02.

10 The Conference appointed a committee to study federal habeas procedure in 1942. See Judicial Conference of Senior Circuit Judges, Report of the Judicial Conference 18 (1942) [hereinafter cited as 1942 REPORT]. The work of the committee is recounted by its chairman in Parker, Limiting the Abuse of Habeas Corpus, 8 F.R.D. 171, 173 (1949). See also United States v. Hayman, 342 U.S. 205, 214-15 (1952).

4 Judiclal Conference of Senior Circuit Judges, Report of the Judicial ConferENCE 22 (1943) [hereinafter cited as 1943 REPORT].

42 See Hayman, 342 U.S. at 215.

4s 1943 REPORT, supra note 41, at 23. This jurisdictional bill was introduced in Congress in 1945. H.R. 4233, 79th Cong., 1st Sess. (1945); S. 1451, 79th Cong., 1st Sess. (1945). A substitute version was introduced in 1946. H.R. 6723, 79th Cong., 2d Sess. (1946). No action was taken on either proposal. The 1946 bill, along with a version further revised by the Conference's habeas corpus committee, was circulated among the members of the Judicial Conference early in 1947. See Judicial Conference op Senior Circuit Judges, Report or THE Judicial Conference 268 app. (1947) [hereinafter cited as 1947 RePorT]. The Conference took no official action on these proposals.

4T The House approved the new Code on July 7, 1947. 93 Cong. Rec. 8392 (1947).

45 1947 REPoRT, supra note 43, at 17 . One amended $\$ 2244$, which delineates the finality of habeas corpus determinations. It is of interest that the proposal approved by the Conference in 1943 included a res judicata provision for habeas corpus determinations. See 1943 REPORT, supra note 41, at 23-24. The version of $\S 2244$ approved by the Conference in 1947 permits a second application presenting the same grounds if the judge finds that "the ends of justice" require it. See 1947 REPORT, supra note 43, at 17-18. The other amendment modified the exhaustion requirement. See 1947 REPoRT, supra note 43 , at 17-18. Both amendments were prepared by the Conference committee appointed in 1942. See Senate Report, supra note 36, at 9, reprinted in 1948 U.S. Code Cong. SERv. (Special Supp.) at 1683.

(s See 94 Cong. Rec. 7930, 8501 (1948) (Senate and House votes, respectively). There are insignificant variations from the language adopted by the Conference. Compare SENATE RBPort, supra note 36, at 9-10, reprinted in 1948 U.S. Code Cong. Serv. (SpEcial Supp.) at 1683-84 with 1947 REPORT, supra note 43 , at 17-18. 
be satisfied for the court to have power to act; ${ }^{47}$ it cannot be waived. ${ }^{48}$ Although jurisdiction has several meanings ${ }^{49}$ and does not always indicate a requirement that is absolute and not subject to waiver or forfeiture, ${ }^{\text {s0 }}$ the language proposed by the Judicial Conference in 1943 made clear that the Conference intended for the exhaustion requirement to limit the subject matter jurisdiction of the federal courts. ${ }^{51}$ Section 2254 , however, as endorsed by the Conference in $1947^{52}$ and as enacted into law, ${ }^{58}$ contained no reference to jurisdiction. Instead of declaring that "no Circuit or District Judge of the United States shall have jurisdiction to issue a writ of habeas corpus," section 2254 provided that "[a]n application for a writ of habeas corpus . . . shall not be granted unless it appears that the applicant has exhausted the remedies available in the courts of the State." Although the Senate Judiciary Committee described exhaustion of state remedies as "a ground for federal jurisdiction," the statute itself is worded as a limitation on the

47 See Cooper v. Reynolds, 77 U.S. (10 Wall.) 308, 316 (1870); Ex parte McCardle, 74 U.S. (7 Wall.) 506, 512 (1869); Rhode Island v. Massachusetts, 37 U.S. (12 Pet.) 657, 718 (1838). Cf. Bell v. Hood, 327 U.S. 678, 682 (1946) (distinguishing pleading requirements necessary to establish a court's subject matter jurisdiction from those a claimant must satisfy to prevail on the merits).

18 See Zipes v. TWA, 455 U.S. 385, $392-93$ (1982); Rhode Island v. Massachusetts, 37 U.S. (12 Pet.) 657, 718 (1838).

"T "The word is a term of large and comprehensive import, and embraces every kind of judicial action." Brack's Law Dictionary 766 (rev. 5th ed. 1979).

${ }^{30}$ In Zipes, the Court acknowledged that it had referred to the requirement in question as "jurisdictional" on several occasions but still held that it was not a "jurisdictional prerequisite." 455 U.S. at 393. See also infra notes 148-53 and accompanying text (discussing Zipes).

81 [N]o Circuit or District Judge of the United States shall have jurisdiction to issue a writ of habeas corpus to inquire into the validity of imprisonment of a prisoner held in custody pursuant to a conviction of a court of any state, or to release such prisoner in any habeas corpus proceeding, unless it shall appear that the petitioner has no adequate remedy .... in the courts of the state.

1943 REPORT, supra note 41, at 23.

s2 See supra note 45 and accompanying text.

s2 Judicial Code of 1948, ch. 646, $\$ 2254,62$ Stat. 689, 967 (codified as amended at 28 U.S.C. \& 2254(b)-(c) (1976)).

H 1943 Rsport, supra note 41, at 23 (emphasis added).

3828 U.S.C. \& 2254(b) (1976) (emphasis added). See SBNaTE RePoRT, supra note 36, at 9, reprinted in 1948 U.S. Codr Cong. Serv. (Sprcial Supp.) at 1683.

se Senate Rzport, supra note 36, at 10, reprinted in 1948 U.S. Code Cong. SERv. (SPECral Supp.) at 1684. The Judiciary Committee reported an amended version of $\S 2254$, following the recommendations of the Judicial Conference, see supra note 45, one of the purposes of which was

to eliminate, as a ground of Federal jurisdiction to review by habeas corpus judgments of State courts, the proposition that the State court has denied a prisoner a "fair adjudication of the legality of his detention under the Constitution and laws of the United States." The Judicial Conference believes that this would be an undesirable ground for 
availability of the remedy of a writ of habeas corpus, not as a restriction of jurisdiction. ${ }^{57}$

\section{Structure of Federal Habeas Corpus Legislation}

The habeas corpus chapter of the 1948 Judicial Code ${ }^{88}$ begins with section 2241, which sets out the "[p] ower to grant the writ." The exhaustion requirement was placed in section 2254 under the caption "[s]tate custody; remedies in State courts." The power of the federal courts in section 2241 to grant the writ is not limited by any reference to exhaustion of state remedies, ${ }^{61}$ and the exhaus-

Federal jurisdiction in addition to exhaustion of State remedies or lack of adequate remedy in the State courts because it would permit proceedings in the Federal court on this ground before the petitioner had exhausted his State remedies. This ground would, of course, always be open to a petitioner to assert in the Federal court after he had exhausted his State remedies or if he had no adequate State remedy.

Senate Report, supra note 36, at 10, reprinted in 1948 U.S. Code Cong. SeRv. (Special SuPP.) at 1689. The final sentence in the quoted passage suggests that "ground" of jurisdiction is being used more in the sense of ground for relief than ground for subject matter jurisdiction. $C f$. Bell v. Hood, 327 U.S. 678, 682 (1946) (distinguishing pleading requirements necessary to establish subject matter jurisdiction from those necessary to prevail on the merits).

${ }^{87}$ The existence of the Conference's jurisdictional bill and the statement in the House Report on the Code revision that "[t]he habeas corpus chapter has been rewritten to conform with legislation pending in Congress and approved by the Judicial Conference," House REport, supra note 19, at 7, reprinted in 1948 U.S. Code Cong. SERv. (Speciar Supp.) at 1698, provides inferential evidence of a conscious choice not to make exhaustion of state remedies a jurisdictional requirement. The drafting committees were aware of the Conference's proposals and used them in drafting $\S 2254$, id., reprinted in 1948 U.S. CoDE Cong. Serv. (Special Supp.) at 1698, but the jurisdiction language still was not included.

ss Judicial Code of 1948, ch. 646, $\S \S 2241-2255,62$ Stat. 869, 964-68 (codified as amended at 28 U.S.C. $\$ \S 2241-2255$ (1976)).

s\$ 28 U.S.C. \$ 2241 (1976).

so Judicial Code of 1948, § 2254, 62 Stat. at 967 (amended in 1966 to read "State custody; remedies in Federal Courts") (codified as amended at 28 U.S.C. $\$ 2254$ (1976)).

o1 Federal power to issue the writ is limited by five jurisdictional predicates in $\S$ 2241(c):

(c) The writ of habeas corpus shall not extend to a prisoner unless

(1) He is in custody under or by color of the authority of the United States or is committed for trial before some court thereof; or

(2) $\mathrm{He}$ is in custody for an act done or omitted in pursuance of an Act of Congress, or an order, process, judgment or decree of a court or judge of the United States; or

(3) He is in custody in violation of the Constitution or laws or treaties of the United States; or

(4) $\mathrm{He}$, being a citizen of a foreign state and domiciled therein, is in custody for an act done or omitted under any alleged right, title, authority, privilege, protection, or exemption claimed under the commission, order or sanction of any foreign state, or under color thereof, the validity and effect of which depend upon the law of nations; or

(5) It is necessary to bring him into court to testify or for trial. 
tion requirement is not colored by language purporting to affect the jurisdiction of the federal courts. ${ }^{62}$

Congress amended section 2254 in $1966,{ }^{63}$ moving its then existing language into subsections (b) and (c) ${ }^{64}$ and adding subsections (a) and (d) through (f).$^{65} \mathrm{New}$ subsection (a) provides, ${ }^{66}$ in effect, that the grounds stated in section $2241(\mathrm{c})(3)^{67}$ provide the only predicate for federal jurisdiction over the habeas corpus claims of state prisoners: the federal court "shall entertain an application for the writ" if the petitioner claims he is held in violation of the Constitution, laws, or treaties of the United States. ${ }^{68} \mathrm{By}$ reiterating that an alleged violation of federal law provides jurisdiction, the amendment is further evidence that the exhaustion requirement limits the availability of a remedy, not the court's jurisdiction. ${ }^{69}$ Section 2254 (b) provides simply that "[a]n application shall not be granted" unless state remedies are exhausted. ${ }^{70}$

\section{Policies Underlying the Exhaustion Requirement}

The language, structure, legislative history, and pre-Code background of the exhaustion requirement lend virtually no support to the proposition that the requirement was intended to be a

28 U.S.C. § 2241(c) (1976).

22 Indeed, Congress eschewed such language in drafting the exhaustion requirement. See supra notes 54-57 and accompanying text.

es Act of Nov. 2, 1966, Pub. L. No. 89-711, § 2, 80 Stat. 1104, 1105-06 (1966). The purpose of the amendment was to "revise the procedures applicable to review by lower Federal courts of habeas corpus petitions by State convicts." S. REP. No. 1797, 89th Cong., 2d Sess. 1 (1966) [hereinafter cited as 1966 SEnate Report], reprinted in 1966 U.S. Code Cong. \& Ad. News 3663, 3663. See also H.R. Rep. No. 1892, 89th Cong., 2d Sess. 3 (1966) [hereinafter cited as 1966 House REPORT].

or See Pub. L. No. 89-711, § 2(c), 80 Stat. at 1105 (codified at 28 U.S.C. § 2254(b)-(c) (1976)).

${ }^{6 s}$ See Pub. L. No. 89-711, $\S 2$ (d), 80 Stat. at 1105-06 (codified at 28 U.S.C. $\S 2254$ (a), (d)-(f) (1976)).

os The Supreme Court, a Justice thereof, a circuit judge, or a district court shall entertain an application for a writ of habeas corpus in behalf of a person in custody pursuant to the judgment of a State court only on the ground that he is in custody in violation of the Constitution or laws or treaties of the United States.

28 U.S.C. $\$ 2254$ (a) (1976) (emphasis added, indicating language appearing in § 2241(c)(3), see supra note 61 ).

${ }^{67} 28$ U.S.C. $\$ 2241(\mathrm{c})(3)$ (1976), reprinted supra note 61.

6828 U.S.C. $\$ 2254$ (a) (1976) (emphasis added). This appears to have been understood by the federal bench even before the amendment. See Fay v. Noia, 372 U.S. 391, 426 (1963) ("we have consistently held that federal court jurisdiction is conferred by the allegation of an unconstitutional restraint").

so See 1966 House RePoRT, supra note 63, at 8; supra note 54-57 and accompanying text.

7028 U.S.C. \& 2254(b) (1976) (emphasis added). 
limitation on the jurisdiction of the federal courts that cannot be waived, forfeited, or conceded. The Supreme Court was faced with a similar lack of congressional direction when it recently construed the exhaustion requirement in Rose $v$. Lundy. ${ }^{71}$ There, ${ }^{72}$ as in a number of earlier cases, ${ }^{73}$ the Court examined the policies and purposes behind the requirement to determine the proper construction of the statute. This part looks at those policies and purposes to see what answers they indicate for the problem of waiver and forfeiture.

\section{A. Comity and Federalism}

The very existence of federal habeas corpus review of state court convictions threatens to disrupt the delicate balances required by a federal system of interlocking layers of government. ${ }^{44}$ Since 1886, federal courts have voluntarily limited their consideration of habeas corpus petitions to prevent "unnecessary conflict" between federal and state courts. ${ }^{75}$ The theory is that, with a few limited exceptions, ${ }^{78}$ federal-state conflict can be minimized and the purposes of federal habeas corpus protection can be served if federal relief is available only after the state has had a full opportunity to settle the prisoner's claim in its own courts. ${ }^{77}$ The rule of

11455 U.S. 509 (1982).

$72 \mathrm{Id}$. at 515.

7s See, e.g., Roberts v. LaVallee, 389 U.S. 40, 43 (1967) (per curiam) (Court looked to purposes behind the exhaustion requirement in holding that a petitioner had exhausted state remedies even though state courts changed their interpretation of the substance of his claim following his appeal); Fay v. Noia, 372 U.S. 391, 415-26, 435 (1963) (Court conducted wide-ranging inquiry into policies and purposes behind exhaustion requirement in deciding that it applied only to remedies available when the prisoner applied for federal relief); Brown v. Allen, 344 U.S. 443, 447-50 (1953) (Court held it would not be consistent with requirement's purposes to insist that petitioner pursue collateral state remedies). Cf. Hensley v. Municipal Court, San Jose-Milpitas Judicial Dist., 411 U.S. 345, 350 (1973) ("we have consistently rejected interpretations of the habeas corpus statute that would suffocate the writ in stifling formalisms or hobble its effectiveness with the manacles of arcane and scholastic procedural requirements").

"See Hensley, 411 U.S. at 351 ("habeas corpus is an extraordinary remedy whose operation is to a large extent uninhibited by traditional rules of finality and federalism").

${ }^{73}$ Ex parte Royall, 117 U.S. 241, 251 (1886), quoted supra text accompanying note 28.

76 See, e.g., United States ex rel. Kennedy v. Tyler, 269 U.S. 13, 17 (1925) (exhaustion requirement does not apply to cases "where exceptional circumstances of peculiar urgency are shown to exist"); 28 U.S.C. $\S 2254$ (b) (1976) (exhaustion of state remedies not necessary where state remedies would be "ineffective").

77 The federal courts should not "presume that the decision of the State court would be otherwise than is required by the fundamental law of the land, or that it would disregard the settled principles of constitutional law announced by [the Supreme Court]." Royall, 117 U.S. at 252. Cf. Darr v. Burford, 339 U.S. 200, 204 (1950) ("it would be unseemly in our dual system of government for a federal district court to upset a state court conviction without 
exhaustion is thus "rooted in considerations of federal-state comity"78 and helps avoid friction between state and federal governments. ${ }^{79}$

The exhaustion doctrine also serves to "protect the state courts' role in the enforcement of federal law," fostering the development of state law on federal issues and increasing state court familiarity with federal law..$^{80}$ By enabling state superior courts to correct the errors of lower state courts on appeal, ${ }^{81}$ the exhaustion requirement allows state high courts to supervise their lower courts and create a coherent body of state law and state interpretation of constitutional law.

The policy of avoiding federal-state friction would seem to support allowing states to waive or concede the requirement. If the state does not object to the federal court hearing the petition, there is significantly less chance of federal-state conflict over the case. It is not clear, however, that waiver eliminates the possibility for friction. The state's various interests may not be perfectly represented by the prosecutor who waives the requirement. Although state's attorneys are charged with representing the interests of their state, ${ }^{82}$ they may not always be mindful of the state superior

an opportunity to the state courts to correct a constitutional violation"), overruled in part, Fay v. Noia, 372 U.S. 391, 435 (1963).

${ }^{73}$ Preiser v. Rodriguez, 411 U.S. 475, 491 (1973). Although criticized as a vague concept, see Francis v. Henderson, 425 U.S. 536, 548-50 (1976) (Brennan, J., dissenting), comity is commonly invoked to characterize the purpose of the exhaustion requirement. See Rose v. Lundy, 455 U.S. 509, 515, 518 (1982); Picard v. Connor, 404 U.S. 270, 275 (1971); Fay v. Noia, 372 U.S. 391, 419-20 (1963); Franklin v. Oregon, 662 F.2d 1337, 1347 (9th Cir. 1981); Jones v. Shell, 572 F.2d 1278, 1280 (8th Cir. 1978). The doctrine of comity "teaches that one court should defer action on causes properly within its jurisdiction until the courts of another sovereignty with concurrent powers, and already cognizant of the litigation, have had an opportunity to pass upon the matter." Darr v. Burford, 339 U.S. at 204. See also Younger v. Harris, 401 U.S. 37, 44 (1971) (comity reflects the "belief that the National Government will fare best if the States and their institutions are left free to perform their separate functions in their separate ways").

7" Rose v. Lundy, 455 U.S. at 518 (quoting Duckworth v. Serrano, 454 U.S. 1, 3-4 (1981) (per curiam)); Fay v. Noia, 372 U.S. at 434-35.

${ }^{\text {so }}$ Rose v. Lundy, 455 U.S. at 518. But cf. Brennan, Some Aspects of Federalism, 39 N.Y.U. L. REv. 945, 957-58 (1964) ("federal habeas corpus jurisdiction should be taken by the States as an opportunity to fashion state remedies as good or better for the disposition of the federal claims of state prisoners").

${ }^{21}$ Cf. Developments in the Law-Federal Habeas Corpus, 83 Harv. L. REv. 1038, 1095 (1970) ("Generally, the interests which underlie the [exhaustion] rule are compelling only with respect to appellate, not collateral, processes. It is the appellate process which most directly provides the higher state courts an opportunity to supervise trial courts and facilitate uniform application of the law .....").

"See, e.g., Mass. AnN. Laws ch. 12, \& 3 (Michie/Law. Co-op. 1980) ("The attorney general shall appear for the commonwealth and for state departments, officers . . . in all suits . . . in which the official acts and doings . . . are called in question, in all the courts of 
court's interest in supervising its lower courts ${ }^{83}$ or of the federal policy to foster development of state law on federal issues.

Imposing forfeiture for failure earlier in the litigation to raise the exhaustion requirement would provoke federal-state conflict. A state objecting belatedly to the federal proceeding is objecting nonetheless. If comity were the only policy to consider, habeas petitions should be held subject to dismissal for nonexhaustion at any time.

\section{B. Efficient Use of Judicial Resources}

Section 2254 was enacted against a background of Supreme Court expansion of the scope of federal habeas corpus review of state court judgments that had resulted in a significant increase in the federal habeas caseload. ${ }^{84}$ That increase was at least partly responsible for the Judicial Conference's proposal to codify the exhaustion requirement. ${ }^{85}$ The grounds for federal habeas review of state convictions continued to multiply in the 1960 's, ${ }^{86}$ leading to

the commonwealth."); N.Y. ExEc. LAw $\S 63$ (McKinney 1982) ("The attorney general shall: (1) prosecute and defend all actions and proceedings in which the state is interested . . . ."); Wyo. Stat. ANN. § 9.2-505 (1977) ("The attorney general shall . . . be required to attend to the interests of the state in all suits, actions or claims in which the state is or may become interested in either the supreme court of the state, or in any of the United States Courts."). See also United States ex rel. Trantino v. Hatrack, 563 F.2d 86, 101-04 (3d Cir. 1977) (Gibbons, J., dissenting), cert. denied, 435 U.S. 928 (1978). Judge Gibbons demonstrated in Trantino that under New Jersey law the attorney general has the duty to appear and defend habeas corpus actions against state officials. Id. He concluded that

in the name of comity the majority has concluded that the New Jersey Courts are not only deserving of respect from the federal judiciary but also in need of protection from a state legislature which has conferred on that State's Attorney General authority to determine the propriety of waiving the exhaustion requirement in a federal habeas corpus proceeding.

Id. at 104.

83 "Exhaustion, then, serves an interest not of state prosecutors but of state courts. It follows, therefore, that the state court interest which underlies the exhaustion requirement of $\S 2254$ (b) cannot be conceded or waived by state prosecutors . . ." Trantino, 563 F:2d at 96 (emphasis in original).

s4 See Parker, supra note 40, at 171-72. After decades of gradual erosion, the Court in 1942 abandoned what remained of the principle that habeas corpus was available only to challenge a conviction by a court that lacked jurisdiction, see Ex parte Watkins, 28 U.S. (3 Pet.) 193, 202-03 (1830), and acknowledged that the writ was available to raise constitutional questions regardless of whether they went to the trial court's jurisdiction. See Waley v. Johnston, 316 U.S. 101, 104-05 (1942). The Court for some time had perpetuated the fiction that constitutional violations robbed the trial court of jurisdiction. See Johnson v. Zerbst, 304 U.S. 458, 468 (1938); Friendly, Is Innocence Irrelevant? Collateral Attack on Criminal Judgments, 38 U. CHI. L. Rev. 142, 151-52 (1970).

ss 1966 House REPORT, supra note 63, at 4-6; Parker, supra note 40, at 173.

se See 1966 House REPORT, supra note 63, at 6; Friendly, supra note 84, at 155-56. 
further increases in the federal caseload ${ }^{87}$ and prompting the 1966 reforms in federal habeas procedure. ${ }^{88}$ Concern for the amount of judicial resources consumed by review of habeas corpus petitions continues to be strong. ${ }^{89}$

Allowing states to waive or concede the exhaustion requirement could affect the federal habeas caseload in a variety of ways depending on the motivation and behavior of state prosecutors. If waivers were used to hasten federal consideration of claims the prosecutor expects will eventually reach federal court, the federal caseload would increase if prosecutors underestimated the likelihood of habeas petitions being finally resolved in state court. Perhaps more important, federal courts would not have the benefit of state court review in such cases. ${ }^{90}$ If, on the other hand, waivers or concessions were used to advise the federal court that claims were indeed exhausted or that there would be no point in further state proceedings, ${ }^{91}$ the court could be spared more detailed examination of these questions. The state's attorney is already required to advise the court "whether the petitioner has exhausted his state remedies" in the answer to the petition. ${ }^{22}$ Allowing the state to waive the requirement would merely relieve the court of the burden of scrutinizing this advice.

A prosecutor might also waive the exhaustion requirement believing the claim to be frivolous and preferring summary federal dismissal on the merits to a round of state proceedings. If the federal court agrees that the claim is frivolous, the court can as easily dismiss the petition on the merits as for failure to exhaust state remedies. ${ }^{93}$ If the federal court disagrees with the prosecutor's assessment of the claim, the waiver would affect demands on the federal court's time. Given an opportunity, the state courts might eliminate the need for any federal review by ruling for the peti-

67 See 1966 House Report, supra note 63, at 6-7; Lay, Problems of Federal Habeas Corpus Involving State Prisoners, 45 F.R.D. 45, 45-46 (1969).

ss See 1966 House Report, supra note 63, at 4-7.

8* See Attorney General's Task Force on Violent Crime, U.S. Dep'T of Justice, FiNAL REPORT 58 (1981). The report complains that the exhaustion requirement has overburdened both federal and state courts and recommends adoption of a three-year statute of limitations for habeas corpus petitions. Id.

- See Laubach, supra note 25 , at 35 (suggesting that prior state adjudication may clarify facts and issues for federal courts).

-1 See supra note 6 and accompanying text.

$\because$ R. Governing Sec. 2254 Cases in U.S. Dist. Cts. 5 [hereinafter cited as Section 2254 RULES], reprinted in 28 U.S.C. § 2254 app. (1976).

os The federal court is already obliged to dismiss claims that are frivolous on their face. See Section 2254 Rules, supra note 92, Rule 4. 
tioner or convincing him that his claim is not worth pursuing. If the state's attorney believed the case could be resolved in state court, however, there would be little incentive for him to avoid such resolution through waiver. It is therefore likely that any claim the prosecutor, but not the federal court, would characterize as frivolous eventually would work its way into federal court. Even so, the federal courts might dispose of these cases more easily with the help of a prior state court review of the claim. ${ }^{94}$ To the extent this is so, allowing waiver of frivolous claims would increase the burden on the federal courts and thus perhaps should not be allowed in habeas cases.

Although it is unclear how waiver or concession of the exhaustion requirement would affect the federal courts' caseload, the impact on federal judicial resources of a state not raising the exhaustion requirement at the proper time provides perhaps the most compelling reason to impose a forfeiture rule. The state's attorney is directed by court rules to address exhaustion of state remedies in the state's initial answer to the habeas petition..$^{95}$ If the issue is not raised until later in the proceedings, time spent considering the petition in the interim will have been wasted if the court cannot declare the issue forfeited but instead must dismiss the petition for failure to exhaust. Forfeiture not only would provide an incentive for the state's attorney to make sure that any exhaustion claims were presented in good time, but also would ensure that federal judicial resources would not be wasted when the state failed to do so. ${ }^{96}$

\section{Expediting Federal Relief}

Federal habeas corpus review exists to protect the right of per-

24 See supra note 90 and accompanying text.

${ }^{95}$ See supra note 92 and accompanying text.

os This argument is supported by the Supreme Court's use of forfeiture in applying the rule of Wainwright v. Sykes, 433 U.S. 72 (1977). Under Sykes, absent a showing of cause and prejudice, a petitioner may not pursue by way of habeas corpus a claim that is barred in the state courts on procedural grounds. Id. at 87 . The Court has refused to consider a Sykes defense when presented for the first time in the Supreme Court: "Considerations of judicial efficiency demand that a Sykes claim be presented before a case reaches this Court." Jenkins v. Anderson, 447 U.S. 231, $234 \mathrm{n} .1$ (1980). The Court noted that the application of the Sykes rule may turn on an interpretation of state law that could more efficiently and easily be done by the lower federal courts, which should be more familiar with state law. Id. Cf. Rummel v. Estelle, 445 U.S. 263, 267 n.7 (1980) (although state argues petition is barred by Sykes, Court defers to contrary interpretation of state law by federal court of appeals). The applicability of the exhaustion requirement also will frequently turn on an interpretation of state law. 
sonal liberty. ${ }^{97}$ The nature of the writ demands that it be "administered with the initiative and flexibility essential to insure that miscarriages of justice within its reach are surfaced and corrected." The Supreme Court has repeatedly emphasized the need for "speed, flexibility, and simplicity" in its decisions regarding the exhaustion doctrine. ${ }^{99}$ The Court has insisted that habeas corpus not be made "a static, narrow, formalistic remedy"100 and that procedural niceties not be allowed to interfere with the underlying policy of providing a federal forum for those imprisoned in violation of the Constitution or laws of the United States. ${ }^{101}$

Allowing waiver and forfeiture of the exhaustion requirement could only serve to speed claims on their way into federal court. This observation is of limited value, however, since if "obtaining speedy federal relief"102 were the sole consideration there would be no exhaustion requirement at all. By requiring that a petitioner first pursue available state remedies, the exhaustion requirement necessarily slows the progress of habeas petitions to the federal courts. Nevertheless, it is important to note that while the requirement bars many petitioners from the federal courts, the bar is only temporary and not in absolute derogation of "the right of a state prisoner to apply for relief by habeas corpus to the lower federal courts." 103

\section{Summary}

The policies underlying the exhaustion requirement do not provide conclusive answers to the problems of waiver and forfeiture. To promote federal-state comity, waiver and concession should probably be allowed, but forfeiture definitely should not be. Conservation of judicial resources, however, would best be served

97 See, e.g., Bowen v. Johnston, 306 U.S. 19, 26 (1939) (Hughes, C.J.) (habeas corpus is a "precious safeguard of personal liberty"); Ex parte Tom Tong, 108 U.S. 556, 559 (1883) (habeas corpus is the "remedy which the law gives for the enforcement of the civil right of personal liberty").

ss Harris v. Nelson, 394 U.S. 286, 291 (1969), quoted in Hensley v. Municipal Court, San Jose-Milpitas Judicial Dist., 411 U.S. 345, 350 (1973).

" Hensley, 411 U.S. at 350. Cf. Rose v. Lundy, 455 U.S. 509, 520 (1982) (total exhaustion rule not inconsistent with prisoner's interest in obtaining speedy relief); Roberts $v$. LaVallee, 389 U.S. 40, $42-43$ (1967) (refusing to require additional state litigation); Fay v. Noia, 372 U.S. 391, 399-415 (1963) (reviewing history of habeas corpus); Brown v. Allen, 344 U.S. 443,449 n.3 (1953) (refusing to require repetitious applications to state courts).

100 Jones v. Cunningham, 371 U.S. 236, 243 (1963).

101 Fay v. Noia, 372 U.S. at $426-27$.

${ }^{102}$ Rose v. Lundy, 455 U.S. at 520.

${ }^{103}$ Brown v. Allen, 344 U.S. at 450. 
by imposing forfeiture; it is not clear what the effect of allowing waiver would be on the federal habeas docket. Waiver, forfeiture, and concession would all accelerate the progress of claims into federal court-but so would elimination of the exhaustion requirement altogether. To help sort out the priorities and balance these conflicts, the next part looks at how waiver and forfeiture rules have been structured for requirements that serve policies similar to those that underlie the exhaustion requirement.

\section{Waiver and Forfeiture RULEs for Other REquirements}

\section{A. The Eleventh Amendment}

The eleventh amendment to the Constitution prohibits federal courts from hearing private suits against state governments. ${ }^{104}$ The language of the amendment does not equivocate or suggest any exceptions to the prohibition but declares plainly that "[t]he Judicial power of the United States shall not be construed to extend" to such suits against a state. ${ }^{105}$ Nevertheless, states have been allowed to waive the amendment's protection. ${ }^{108}$

By preventing federal adjudication of the states' liabilities, the eleventh amendment serves to eliminate an area of potentially great federal-state friction. Allowing a state to waive the amendment's protection is consistent with this purpose since there can be no federal-state friction when a state voluntarily consents to be sued in federal court. The amendment has not been construed to be an imposition of an unwanted immunity upon the state but rather is seen as a protection of a state's sovereign right to determine whether, when, and where it will be subject to suit. ${ }^{107}$

Although the eleventh amendment may be waived, the Court has consistently required a clear declaration of a state's consent to suit; constructive consent is not looked on with favor. ${ }^{108}$ The Court

104 "The Judicial Power of the United States shall not be construed to extend to any suit in law or equity, commenced or prosecuted against one of the United States by Citizens of another State, or by Citizens or Subjects of any Foreign State." U.S. CoNST. amend. XI. States are also immune from suit in federal court by their own citizens. See Parden v. Terminal Ry., 377 U.S. 184, 186 (1964); Hans v. Louisiana, 134 U.S. 1 (1890).

108 U.S. Const. amend. XI (emphasis added).

10 See Parden, 377 U.S. at 192-93; Ford Motor Co. v. Department of Treasury, 323 U.S. 459, 465 (1945); Missouri v. Fiske, 290 U.S. 18, 24 (1933).

${ }^{107}$ E.g., Clark v. Barnard, 108 U.S. 436, 447 (1883) ("The immunity from suit belonging to a State . . . is a personal privilege which it may waive at pleasure.").

${ }^{108}$ See Edelman v. Jordan, 415 U.S. 651,673 (1974) ("Constructive consent is not a doctrine commonly associated with the surrender of constitutional rights, and we see no place for it here."); Ford Motor Co., 323 U.S. at 468 (waiver not to be presumed in the 
has also stopped short of imposing forfeiture for not raising the eleventh amendment in time, finding that it "sufficiently partakes of the nature of a jurisdictional bar so that it need not be raised in the trial court." 100

The exhaustion requirement was designed to serve federalism interests almost identical to those behind the eleventh amendment. ${ }^{110}$ The arguments for allowing waiver of the eleventh amendment also apply to the exhaustion requirement. ${ }^{111}$ The characteristics of the eleventh amendment that have convinced the Court to make waiver virtually a matter of state policy and to make forfeiture impossible, however, are not found in the exhaustion requirement. The exhaustion requirement was not set up as a jurisdictional bar, ${ }^{112}$ nor does it approach constitutional significance. It is not an absolute, permanent bar to the federal courts but partial and temporary, designed to expire on its own terms, ${ }^{113}$ with exceptions written into the statute. ${ }^{114}$ Waiver and forfeiture, therefore, do not pose as great a threat when applied to the exhaustion requirement as when applied to the eleventh amendment because the interests protected are not as great.

\section{B. The Abstention Doctrine of Younger v. Harris}

The judicially created abstention doctrine articulated in Younger v. Harris ${ }^{110}$ was also designed to prevent conflict between

absence of clear language to the contrary); Great N. Life Ins. Co. v. Read, 322 U.S. 47, 54 (1944) ("clear declaration of the state's intention . . . must be found"). But see Parden, 377 U.S. at 192 (Alabama "consented" to suit by operating railroad after Congress enacted FELA).

108 Edelman, 415 U.S. at 678.

${ }^{110}$ See supra notes 3, 74-81 and accompanying text.

111 See supra text preceeding note 82 and accompanying text.

112 See supra notes 51-57 and accompanying text.

${ }^{113}$ Once state remedies are exhausted, there is no bar to federal habeas proceedings. See supra note 5.

114 See supra note 6.

11501 U.S. 37 (1971). Younger abstention is related to but distinguishable from what is referred to as Pullman abstention, based upon Railroad Comm'n v. Pullman Co., 312 U.S. 496 (1941). See Ohio Bureau of Employment Servs. v. Hodory, 431 U.S. 471, 477 (1977). Pullman allows a federal court to abstain when there is a "possibility that the state courts may interpret a challenged state statute so as to eliminate, or at least to alter materially, the constitutional question presented" in the federal action. Id. Because of this, the Court said in Hodory that Pullman abstention could not be waived, id. at $480 \mathrm{n} .11$, even though Younger abstention was held to be waivable, see infra note 119 and accompanying text. See also Wisconsin v. Constantineau, 400 U.S. 433, 437 (1971) (dictum) (Pullman abstention may be enforced even though state has not requested it). Pullman abstention, though not waivable, nevertheless is not absolute. A federal court is not required to abstain when "the possible benefits of abstention become too speculative to justify or require avoidance of the 
the states and the federal government. ${ }^{116}$ The doctrine requires federal courts to refrain from enjoining state court proceedings so as not to "unduly interfere with the legitimate activities of the States."117 The requirement is not absolute, however. In Ohio $\mathrm{Bu}$ reau of Employment Services $v$. Hodory, ${ }^{118}$ the Court held that the interests protected by the abstention doctrine are not threatened when a state does not contest the propriety of a federal court hearing a case pending in the state's courts: "If the State voluntarily chooses to submit to a federal forum, principles of comity do not demand that the federal court force the case back into the State's own system." 119

For reasons similar to those found for the eleventh amendment ${ }^{\mathbf{1 2 0}}$ and the exhaustion requirment, ${ }^{121}$ waiver is consistent with the purposes of Younger abstention. There can be no undue interference with legitimate state activity ${ }^{122}$ and thus no cause for federal-state friction when a state "voluntarily chooses to submit to a federal forum."12s

\section{Requirements Designed to Protect A Party}

Requirements established solely for the benefit of one of two adversary parties can commonly be waived by that party. Venue, which ensures a party's right to defend in a convenient forum, has been held to be a "personal privilege" for the party to invoke at his

question presented." Hodory, 431 U.S. at 481.

${ }_{110}$ See Schlesinger v. Councilman, 420 U.S. 738, 755-56 (1975) (equating the comity considerations underlying the abstention doctrine and those at the root of the exhaustion requirement).

117 Younger, 401 U.S. at 44.

11431 U.S. 471 (1977).

110 Id. at 480 .

${ }_{120}$ See supra notes $106-08$ and accompanying text.

121 See supra notes 3, 74-83 and accompanying text.

122 See supra note 117 and accompanying text.

123 Hodory, 431 U.S. at 480. Thus the concerns of Pullman abstention differ both from Younger and from exhaustion. Pullman is designed to prevent federal interference in state affairs and to allow federal courts to avoid the burden of deciding unresolved questions of state law and thereby avoid constitutional questions that might be difficult to resolve. See Hodory, 431 U.S. at 477 . Because federal as well as state interests are at stake, the federal court is not obliged to follow the parties' wishes that Pullman abstention be waived. See id. at 280 n.11. Because Younger abstention more simply is "designed to allow the State an opportunity to 'set its own house in order,' " $i d$. at 479-80, the state may waive that opportunity. Similarly, because exhaustion was created initially in response to concerns of comity, and its principal purpose is still to prevent federal-state friction, see supra notes 74-81 and accompanying text; but see supra notes 84-89 and accompanying text (discussing problems of federal caseload), the state interest in waiver is predominant and Younger thus provides a more appropriate analogy. 
choice. ${ }^{124}$ Waiver of venue requirements is now provided by statute $^{125}$ as are waivers of personal jurisdiction ${ }^{126}$ and of process and service requirements. ${ }^{127}$ Indeed, objections based on these requirements must be made in a timely fashion or they are forfeited. ${ }^{128}$ Affirmative defenses, such as res judicata and estoppel, are also forfeited if not asserted at the trial court level. ${ }^{128}$ Governmental parties are capable of waiving and forfeiting these requirements. ${ }^{130}$

Exhaustion of state remedies-a kind of inverted res judicata claim-has been characterized as an affirmative defense by one federal court. ${ }^{131}$ It is certainly "a matter constituting an avoidance"132 of the issues presented by the petitioner. Although the exhaustion requirement was not established solely for the benefit of the state, the state's interests are largely congruent with those the requirement was designed to protect..$^{133}$ Surely no interest of the petitioner would be jeopardized by allowing waiver or imposing forfeiture. It may be, however, that the interests of the federal

124 Panama R.R. v. Johnson, 264 U.S. 375, 385 (1924). The venue statute in question read: "Jurisdiction . . . shall be under the court of the district in which the defendant employer resides or in which his principal office is located." Id. at $382-83$ (quoting Seamen's Welfare Act, ch. 153, \& 20, 38 Stat. 1185 (1915), as amended by Act of June 5, 1920, ch. 250, 41 Stat. 1007 (1920) (current version at 46 U.S.C. $\$ 688$ (1976))). The Court found the use of the word jurisdiction "inapt" and concluded that "such a provision merely confers on the defendant a personal privilege which he may assert, or may waive, at his election." Id. at 384-85.

${ }^{123} 28$ U.S.C. $\$ 1406$ (b) (1976) ("Nothing in this chapter shall impair the jurisdiction of a district court of any matter involving a party who does not interpose timely and sufficient objection to the venue."). The Reviser's note states that $\S 1406(\mathrm{~b})$ is declaratory of the law as held in Panama R.R. v. Johnson, 264 U.S. 375 (1924). "It makes clear the intent of Congress that venue provisions are not jurisdictional but may be waived." 28 U.S.C. $\S 1406$ reviser's note. See also Fed, R. Crv. P. 12(h)(1) ("defense of . . improper venue . . is waived" if not timely filed).

${ }^{126}$ FED. R. Crv. P. 12(h)(1) ("defense of lack of jurisdiction over the person ... waived" if not timely filed).

197 Id.

${ }^{128}$ Rule 12(h)(1), id., uses the term "waived" rather than "forfeited" even though loss of the defense is "without regard to the defendant's state of mind." Westen, supra note 8, at 1214. For a discussion of the distinction between waiver and forfeiture, see supra note 8 . A defense of lack of subject matter jurisdiction can be neither waived nor forfeited. FED. $R$. Crv. P. 12(h)(3) (court to dismiss action "[w] jurisdiction of the subject matter").

130 Fed. R. Civ. P. 8(c) (1980); J. Moore \& J. Lucas, 2A Moore's Federal Practice I 8.27(3), at 8-251 to -255 (2d ed. 1982). See also Henry v. First Nat'l Bank, 595 F.2d 291, 298 n.1 (5th Cir. 1979), cert. denied, 444 U.S. 1074 (1980); Radio Corp. v. Radio Station KYFM, 424 F.2d 14, 17 (10th Cir. 1970).

${ }^{130}$ See, e.g., Panhandle E. Pipe Line Co. v. Federal Power Comm'n, 324 U.S. 635, 639

(1945) (venue may be waived by the federal government).

${ }_{131}$ Santos v. Alaska Bar Ass'n, 618 F.2d 575, 576-77 (9th Cir. 1980) (§ 1983 action).

132 FED. R. Civ. P. 8(c).

13s See supra notes 74-103 and accompanying text. 
courts and of the federal system are sufficiently distinct to prevent a state from treating the exhaustion requirement as a private prerogative. ${ }^{\mathbf{1 3 4}}$

\section{The Tax Injunction Statute}

The statutory prohibition of federal court interference with state taxation systems ${ }^{135}$ has its roots in federal equity practice. ${ }^{136}$ Although the statute is not phrased in jurisdictional terms, the Supreme Court has characterized it as a "broad jurisdictional barrier"137 that has the effect of "cutting back federal equity jurisdiction."138 The Court has not yet had occasion to take this characterization so far as to rule that the statute cannot be waived.

The tax injunction statute protects interests of federalism by preventing unnecessary federal interference with state fiscal administration. ${ }^{139}$ The statute promotes the efficient collection of state revenues and guards against disruption of state budgets. ${ }^{140} \mathrm{As}$ with the eleventh amendment ${ }^{141}$ and the abstention doctrine, ${ }^{142}$ federalism interests would not appear to be threatened once a state waives the protection of the statute. As with the requirements designed to protect one of two adversary parties, ${ }^{143}$ it should not be necessary to insist on enforcing the statute's protection if the state does not desire it. Nevertheless, all the circuit courts that have

134 Note, however, that this argument was insufficient in the contexts of the eleventh amendment and Younger abstention. The state is not the sole beneficiary of the eleventh amendment or of the absention doctrine. Both are designed to protect interests of the federal system generally by reducing federal-state friction. See supra notes 106-08, 116 and accompanying text. States are allowed to waive these requirements not because they are designed for the state's sole benefit, but because there is no possible friction, and thus no threat to the interests of the federal system, when the state does not object to what the requirements forbid. See supra notes 106-07, 119 and accompanying text.

13528 U.S.C. § 1341 (1976) ("The district courts shall not enjoin, suspend or restrain the assessment, levy or collection of any tax under State law where a plain, speedy and efficient remedy may be had in the courts of such State.").

${ }^{1 s e}$ See Rosewell v. LaSalle Nat'l Bank, 450 U.S. 503, 525 (1981); Tully v. Griffin, Inc., 429 U.S. 68,73 (1976). The exhaustion requirement also grew out of judicial practice. See supra notes 18-32 and accompanying text.

${ }^{137}$ Moe v. Confederated Salish \& Kootenai Tribes, 425 U.S. 463, 470 (1976).

138 Rosewell, 450 U.S. at 526 (emphasis in original).

139 See id. at 522; Tully, 429 U.S. at 73.

${ }^{140}$ See Rosewell, 450 U.S. at 522 ("this legislation was first and foremost a vehicle to limit drastically federal district court jurisdiction to interfere with so important a local concern as the collection of taxes"); Perez v. Ledesma, 401 U.S. 82, 127 n.17 (1971) (Brennan, J., concurring in part and dissenting in part).

111 See supra notes 106-08 and accompanying text.

142 See supra note 119 and accompanying text.

${ }^{143}$ See supra notes 124-30 and accompanying text. 
considered the question of waiver under the tax injunction statute have found the Supreme Court's jurisdictional language determinative and therefore have forbidden waiver. ${ }^{144}$

The tax injunction statute is distinguishable from the exhaustion requirement in at least one important respect: there is no clearly articulated policy to provide "speedy federal relief"145 to individuals seeking to escape the effects of allegedly unconstitutional state taxes. Federal law does not give state tax cases any special status or diminish the authority of state court determinations on review in the federal courts, as is the case for habeas corpus petitions. ${ }^{146}$ To the contrary, the tax injunction statute singles out state tax cases for special deference to state interests. The Court attributes the origins of the statute not only to federalism, but to equity practice and to a "recognition of the imperative need of a State to administer its own fiscal operations." 147

\section{E. Title VII's Timely Filing Requirement: Zipes $v$. TWA}

The Supreme Court in Zipes v. TWA ${ }^{148}$ considered Title VII's timely filing requirement, ${ }^{149}$ which the Court had characterized as "jurisdictional" in earlier cases. ${ }^{160}$ The Court pointed out that in those cases "the legal character of the requirement was not at issue."151 The legal character of the requirement was at issue in Zipes, and the Court found its somewhat casual earlier use of the term jurisdictional to be of minimal significance. The Court

14 See City of Burbank v. Nevada, 658 F.2d 708, 709 (9th Cir. 1981); United Gas Pipe Line Co. v. Whitman, 595 F.2d 323, 330 (5th Cir. 1979); Illinois Cent. R.R. v. Howlett, 525 F.2d 178, 180 (7th Cir. 1975), cert. denied, 424 U.S. 976 (1976); City of Houston v. Standard-Triumph Motor Co., 347 F.2d 194, 197 (5th Cir. 1975). But cf. infra notes 148-53 and accompanying text (discussing Zipes v. TWA, 455 U.S. 385 (1982), where, despite jurisdictional language in earlier cases, Court found timely filing requirement waivable).

${ }^{14}$ Rose v. Lundy, 455 U.S. 509, 520 (1982). See supra notes 97-101 and accompanying text.

146 State court judgments have no res judicata effect in federal habeas proceedings; "the - state adjudication carries the weight that federal practice gives to the conclusion of a court of last resort of another jurisdiction on federal constitutional issues." Brown v. Allen, 344 U.S. 443,458 (1953).

147 Tully v. Griffin, 429 U.S. 68, 73 (1976), quoted in Rosewell, 450 U.S. at 522.

148455 U.S. 385 (1982).

149 42 U.S.C. $\$ 2000$ e-5(e) (1976). Section 2000 e-5(e) requires that charges of employment discrimination under Title VII of the 1964 Civil Rights Act, 42 U.S.C. $\$ \S 2000 \mathrm{e}$ to 2000e-17 (1976 \& Supp. V 1981), be filed with the Equal Employment Opportunity Commission within 180 days of the alleged unlawful practice.

${ }^{180}$ See United Air Lines, Inc. v. Evans, 431 U.S. 553, 555 n.4 (1977); Alexander v. Gardner-Denver Co., 415 U.S. 36, 47 (1974); McDonnell Douglas Corp. v. Green, 411 U.S. 792, 798 (1973).

151455 U.S. at 395. 
reached its holding by looking to the structure of Title VII, the congressional policy underlying it, and the reasoning of its earlier cases construing the statute. ${ }^{152}$ All three supported the conclusion that "filing a timely charge of discrimination with the EEOC is not a jurisdictional prerequisite to suit in federal court, but a requirement that, like a statute of limitations, is subject to waiver, estoppel, and equitable tolling."153

The exhaustion requirement is far more complex than Title VII's timely filing requirement; the structure of the legislation, underlying policy and earlier case law do not all point to a single answer to the question of waiver and forfeiture. ${ }^{154}$ Although the formula the Court used in Zipes cannot provide an answer for the exhaustion requirement, it does indicate that the Court is not bound by conclusory labels but is willing to undertake a more functional analysis of the purposes and policies behind the requirement in question.

\section{A Proposed Rule of Waiver and Forfeiture for SECTION 2254}

\section{A. Waiver and Concession}

The strongest argument in favor of allowing states to waive or concede the exhaustion requirement is that it would further the interest in federal-state comity that the requirement was designed to promote. ${ }^{185}$ It would, that is, so long as state's attorneys are fully mindful of all the various state interests at stake in their use of waiver. ${ }^{158}$ Mistrust of state's attorneys might also lead one to speculate that waiver would increase the federal caseload. ${ }^{167}$ Such objections could be made to waiver of any requirement where important state interests are at stake. Nevertheless, state's attorneys have been given authority to waive such important protections as the Younger absention doctrine ${ }^{158}$ and the substantive defenses of res judicata and estoppel, ${ }^{180}$ as well as less weighty procedural requirements. ${ }^{160}$

\footnotetext{
162 Id. at 393.

1ss Id. (footnote omitted).

${ }^{154}$ See supra part II.

185 See supra notes 74-81 and accompanying text.

${ }^{138}$ See supra notes $82-83$ and accompanying text.

${ }^{167}$ See supra notes $90-94$ and accompanying text.

${ }_{168}$ See supra note 119 and accompanying text.

${ }^{160}$ See supra notes $129-30$ and accompanying text.

${ }^{100}$ See supra notes $124-27,130$ and accompanying text.
} 
The rules for habeas cases in the federal district courts, far from indicating suspicion, make explicit the court's dependence on state's attorneys in habeas cases. ${ }^{161}$ The advisory committee that drafted the rules recognized that the state's attorney "has both the legal expertise and access to the record and thus is in a much better position [than the petitioner] to inform the court on the matter of exhaustion of state remedies."162 If there is a peculiar reason to mistrust state's attorneys in habeas cases it was not evident to the rules committee or the many district courts that had previously adopted similar local rules. ${ }^{163}$ Absent more than speculative objections that have not been persuasive in other contexts, the policy interests that would be furthered by waiver and concession should justify allowing them.

\section{B. Forfeiture}

The rules for habeas cases make it unlikely that a state's attorney would neglect to address exhaustion at all, ${ }^{164}$ but they leave open the possibility that the state's answer could later prove incorrect or incomplete regarding exhaustion of remedies. The principal policies behind the exhaustion requirement conflict over whether the state should be barred at some point from bringing evidence of the petitioner's failure to exhaust state remedies before the court. To promote federal-state comity, forfeiture should not be imposed; ${ }^{\mathbf{1 6 5}}$ to conserve judicial resources, some final line for raising an exhaustion defense should be drawn. ${ }^{168}$ The petitioner's interest in swift adjudication also supports a rule of forfeiture. ${ }^{167}$

It would not be aberrational for a state's failure to raise exhaustion defenses at trial to preclude consideration of them on appeal. ${ }^{188}$ Rules requiring forfeiture of untimely claims provide an in-

161 Secrion 2254 Rules, supra note 92, Rule 5. One circuit court has held that the court is virtually bound to receive an answer from the state before taking any action on the petition. See Stokes v. Estelle, 593 F.2d 21, 22 (5th Cir. 1979) (per curiam) (neither the habeas corpus statute nor the rules permit a court to dismiss the petition on the basis of an ex parte investigation of the magistrate without requiring an answer from the state); Scott v. Estelle, 567 F.2d 632, 633-34 (5th Cir. 1978) (per curiam) (answer is required whenever the petition alleges facts which, if proven, would show denial of effective assistance of counsel).

${ }^{182}$ Section 2254 Rulzs, supra note 92, Rule 5 advisory committee note.

363 Id.

1es See id., Rule 5.

${ }^{165}$ See supra text following note 83.

16e See supra notes 95-96 and accompanying text.

${ }^{167}$ See supra notes 97-101 and accompanying text.

168 Cf., e.g., Dorszynski v. United States, 418 U.S. 424, 431 n.7 (1974) (Court need not consider issues not raised by appellant in lower courts); Irvine v. California, 347 U.S. 128, 
centive, necessary for the efficient operation of an appellate system, for parties to raise in the trial court all issues that may dispose of their case. Still, some requirements, such as the eleventh amendment, are of such importance that forfeiture will not be imposed for failure to raise them in a timely fashion. ${ }^{169}$

While the exhaustion requirement serves important federalism interests similar to those informing the eleventh amendment, ${ }^{170}$ it can hardly be said to rise to the level of a constitutional barrier. For purposes of forfeiture, the exhaustion requirement is more on a par with such affirmative defenses as res judicata and estoppel. ${ }^{171}$ A flexible, ${ }^{172}$ judicially crafted doctrine, ${ }^{173}$ it has always been concerned with the efficient operation of the federal courts as well as with federal-state comity. ${ }^{174}$ Giving the state the opportunity and obligation to make the court aware of the petitioner's failure to exhaust state remedies at the commencement of federal habeas proceedings ensures that the state's interests, and those of the federal system, will not be overlooked; holding the state to the position it takes regarding exhaustion in the trial court would help ensure that federal judicial resources will not be needlessly expended.

\section{Conclusion}

The problem of whether the exhaustion requirement can be waived or forfeited did not arise prior to its codification in 1948 . Congress left no sign in the legislative history of having anticipated the problem and provided no guidance for its resolution. The exhaustion requirement was created to promote federal-state comity while responding to the need to safeguard individual liberty. It was codified for those reasons and to limit the use of federal judicial resources. Although these policies can operate at cross-purposes, this comment has argued that it is most consistent with them and

129-30 (1954) (Court need not consider issues not raised in petition for certiorari); FkD. $R$. CIv. P. 8(c), 12(h)(1) (certain defenses waived if not timely raised). See also supra note 96 (discussing timing of Sykes claims).

169 See supra note 109 and accompanying text.

170 Compare supra notes 74-79 and accompanying text with supra note 107 and accompanying text.

\footnotetext{
171 See supra notes 74-83, 131-34 and accompanying text.

172 See supra notes 99-100 and accompanying text.

173 See supra notes 18-32 and accompanying text.

174 See supra notes 84-89 and accompanying text.
} 
with the treatment of comparable requirements to allow states to waive or concede the exhaustion requirement and to require the forfeiture of any exhaustion defense not raised in the trial court. 